\title{
Performance Evaluation of Six Microorganisms Utilized for the Treatment of Lead Contaminated Agricultural Soil
}

\author{
${ }^{* 1}$ ATIKPO, E; ${ }^{2}$ MICHEAL, A \\ ${ }^{*}$ Civil Engineering Department, Faculty of Engineering, Delta State University, Oleh Campus, PMB 1, Abraka, Delta State, Nigeria \\ ${ }^{2}$ Department of Animal and Environmental Biology, Faculty of Sciences, University of Benin,PMB 1154, Benin City, Edo State, Nigeria \\ *Corresponding Author Email: eguasbridge@ gmail.com; eatikpo@delsu.edu.ng; +2348038665352 \\ ${ }^{2}$ Email:mimimichaels2@gmail.com; +2348130257425
}

\begin{abstract}
This work focused on the ability of six indigenous microorganisms (Arthrobacter nicotiniae, Bacillus substilis, Klebsiella pneumoniae, Proteus mirabilis, Trichophyton interdigtae and Onychocola canadensis) isolated from contaminated agricultural soil obtained from Ishiagu forest in Ebonyi State, Nigeria for the removal of lead $(\mathrm{Pb})$ ion from the soil. The weights of organisms, nutrient dosage, temperature, $\mathrm{pH}$ and stirring frequency were optimized for the removal of the metal ion from the soil. The data revealed that Bacillus subtilis, Klebsiella pneumoniae and Arthrobacter nocotiniae were found to reduce the metal concentration below recommended standard at time 14 days with respective efficiencies of $58.25 \%, 60.64 \%$ and $60.80 \%$ at the 14 days; and $78.25 \%, 76.19 \%$ and $79.78 \%$ at time 35 days; while Proteus mirabilis, Onychocola canadensis and Trichophyton interdigtae were found to reduce the metal concentration at time 21 days with respective efficiencies of $51.74 \%, 44.65 \%$ and $48.08 \%$ at time 21 days; and $59.67 \%, 51.13 \%$ and $55.27 \%$ at time 35 days. The study showed that the organisms can be utilized to remove $\mathrm{Pb}$ ion from the contaminated soils. Arthrobacter nicotiniae showed the greatest removal capacity with time, followed by Bacillus substilis, and then Klebsiella pneumoniae; before Proteus mirabilis, Trichophyton interdigtae and Onychocola canadensis in that order.
\end{abstract}

\section{DOI: https://dx.doi.org/10.4314/jasem.v22i7.18}

Copyright: Copyright $(0) 2018$ Atikpo and Michael. This is an open access article distributed under the Creative Commons Attribution License (CCL), which permits unrestricted use, distribution, and reproduction in any medium, provided the original work is properly cited.

Dates: Received: 08 May 2018; Revised: 20 June: 2018; Accepted: 30 June 2018

Keywords: Bioremediation, contaminated soil, removal efficiency and lead

Pollution through heavy metals has emerged a serious environmental issue these days (Vargas - Garcia et al., 2012); and pollution of arable land was turning intense in the world (Shu et al., 1998). This has also become the case of Amaonye - Ishiagu forest soils in Ebonyi State of Nrgeria. The soils, as reported by Atikpo (2016); and Ezeh and Chukwu (2011) are highly polluted by lead. This pollution status was linked with metals mining in the forest (Atikpo, 2016; Ezeh and Chukwu, 2011; Nwanguo, 2008). Soils, if polluted, transmit pollution to plants, air and water bodies; and further pose a serious threat to plants, animals and humans (Atikpo, 2016). Lead pollution is to be resisted because of its dangerous effects on the ecosystem. Lead, an environmental contaminant, lacks biological role but toxic to microorganisms (Sobolev and Begonia, 2008). At low concentration even, it is highly toxic and goes with high health implications (Begum et al., 2009) such as intelligence reduction in children (Badawy et al., 2013), anemia, encephalopathy, renal dysfunction and palsy (Athar and Vohora, 2006). This has necessitated the protection of our soils from lead pollution. And in situations where soils are polluted by this metal, treatment option should not be handled with levity.
Different treatments methods are available. These include physical, chemical and biological approaches. Bioremediation, a biological approach to lead removal from soil has proven to be the most cost effective and eco - suitable method. The findings of previous research works on the edge of bioremediation over other remediation approaches are the reasons for the selection of indigenous microorganisms utilized in this work to bring treatment solution to Amaonye contaminated agricultural land - with the major aim of selecting the most effective organism through the process of comparative study. This work also seeks to provide contribution to the existing knowledge on the suitability of these organisms for lead removal from contaminated soils.

\section{MATERIALS AND METHODS}

Materials and Preparation: Materials: Soil samples collected from Amaonye forest in Ishiagu communities, Ebonyi State in Nigeria, Petris dishes, beakers, cotton wool, measuring cylinders, microscope, inoculating needles, refrigerator, MacCartney bottles, hot plate, autoclave, whatman 
filter papers, incubator, atomic absorption spectrophotometer, wire loops, pipette, conical flasks. Reagents: These include nitric, perchloric and sulphuric acids; methylene blue, crystal violent, Lugo's iodine, hydrogen peroxide, ethanol, oxidase reagent, hydrochloric acid, Kovac's reagent, sodium hydroxide and safranin.

Agars/Nutrients and Preparation: Adhering to manufacturers' directions and the method of Cheesebrough (2000), 28, 52 39, 24, 65 and 15 grams of powered nutrient agar, MacConkey agar, potato dextrose agar, Simon Citrate agar, triple sugar iron agar and peptone water powder respectively were soaked and swirled in one liter each of distilled water for 10 minutes. The solutions were autoclaved for 15 minutes, at $121^{\circ} \mathrm{C}$ and $1.5 \mathrm{psi}$ and cooled to $45^{\circ} \mathrm{C}$ before usage.

Characterization of Organisms: Bacteriological and mycological studies were conducted on the soil samples in Micro Biology Laboratories of the Delta State University, Abraka, Delta State, Nigeria. Applying the pure plate techniques, $0.1 \mathrm{ml}$ each of serial diluted solution was inoculated into various sterile Petri-dishes labeled for nutrient, MacConkey and potato dextrose agars respectively from $10^{-1}, 10^{-3}$ and $10^{-5}$ diluents; and distributed on with media (Cowan, 1993 and Baron et al., 1994).The respective inoculated plates with Nutrient agar and MacConkey agar, being inverted, were incubated at a temperature of $37^{\circ} \mathrm{C}$ for 24 hours, while the potato dextrose agar plates were placed at temperature of $28^{\circ} \mathrm{C}$ for 48 hours to 72 hours (Cheesebrough, 2000). Microorganisms Colonies that developed were counted, recorded and sub cultured. The bacterial isolates were characterized and identified with the methods given by (Holt et al., 1994; Cowan and Steel, 1990). The fungi isolates were identified according to the procedure given by (Barnett and Hunter, 1972; Hanigan and MacCane, 2002). Biochemical tests for bacterial were performed in accordance with the methods of Cheesebrough (2000).

Optimal Factors for Remediation Study: The purpose of this is to select the optimal values of factors (dosage of nutrient, weights of organisms, temperature, $\mathrm{pH}$ and stirring frequency) necessary for lead removal capabilities evaluations. The evaluations were carried out in triplicate (Lima et al., 2007; Atikpo, 2016) with varied nutrient dosage of 2, 4, 6, 8, 10, 12 and $14 \mathrm{ml}$ introduced into eighteen $50 \mathrm{ml}$ beakers with $3 \mathrm{~g}$ each of soil and inoculated with 24 and 48 hours old bacteria and fungi respectively for 14 days. The soils were evaluated for lead concentration with Atomic Absorption Spectrophotometer (GBC SensAA, Model no. A6358) on the $14^{\text {th }}$ day, following the elimination of the organisms from the samples with a centrifuge. The same process was followed to determine the optimal values of organism' weights, temperature, $\mathrm{pH}$ and stirring frequency from $1,2,3,4,5,6$, and $7 \mathrm{~g}$ organisms; 20, 25, 30, 35, 40 and $45^{\circ} \mathrm{C}$ temperature for bacteria and 10, 15, 20, 25, 30 and $35^{\circ} \mathrm{C}$ for fungi; 4, $5,6,7,8,9$ and 10 of $\mathrm{pH}$; and $0,1,2,3,4,5$ and 6 per week (pw) stirring frequency respectively. The optimal values of the studied factors were selected and recorded.

Determination of Removal Capabilities: This was carried out in triplicate with the six individual organisms to evaluate their performances on lead removal from the soil using the methods of Lima et al. (2007) and Atikpo (2016). The selected optimal weights of the organisms were inoculated into $3 \mathrm{~g}$ each of soil in ninety $50 \mathrm{ml}$ beakers (eighteen for each organism); and the samples (soils) conditions were adjusted to the selected optimal values of factors in the respective order of organisms' weights $(\mathrm{g})$, dosage of nutrient $(\mathrm{ml})$, temperature $\left({ }^{\circ} \mathrm{C}\right), \mathrm{pH}$ and stirring frequency (pw) of $1 \mathrm{~g}, 8 \mathrm{ml}, 30^{\circ} \mathrm{C}, 7$ and $6 \mathrm{pw}$ for Proteus mirabilis; $5 \mathrm{~g}, 8 \mathrm{ml}, 30^{\circ} \mathrm{C}, 8$ and $6 \mathrm{pw}$ for Bacillus subtilis; $5 \mathrm{~g}, 12 \mathrm{ml}, 30^{\circ} \mathrm{C}, 7$ and $6 \mathrm{pw}$ for Klebsiella pneumoniae; $1 \mathrm{~g}, 10 \mathrm{ml}, 25^{\circ} \mathrm{C}, 7$ and $6 \mathrm{pw}$ for Onychocola canadensis; $1 \mathrm{~g}, 8 \mathrm{ml}, 25^{\circ} \mathrm{C}, 6$ and $6 \mathrm{pw}$ for Trichophyton interdigitae; and $1 \mathrm{~g}, 6 \mathrm{ml}, 30^{\circ} \mathrm{C}, 7$ and $6 \mathrm{pw}$ for Arthrobacter nicotiniae. The soils residual lead ion was evaluated at times 7, 14, 21, 28 and 35 days with Atomic Absorption Spectrophotometer (GBC SensAA, Model no. A6358) after centrifuging to eliminate the organisms from the soil samples.

The lead ion removed with time in $(\mathrm{mg} / \mathrm{kg})$ and the efficiency of removal in $(\%)$ were determined from Equations (1) and (2) (Badmus et al., 2007).

$\mathrm{q}_{\mathrm{t}}=\frac{\left(C_{o}-C_{t}\right)}{m} \cdot V$

$\varepsilon=\frac{\left(C_{o}-C_{f}\right)}{C_{o}} .100$

$C_{0}, \mathrm{C}_{\mathrm{t}}, \mathrm{C}_{\mathrm{f}}, \mathrm{V}$ and $\mathrm{m}$ are the initial lead ion in $\mathrm{mg} / \mathrm{kg}$ present in soil; residual lead ion in soil with time in $\mathrm{mg} / \mathrm{kg}$, final lead ion $(\mathrm{mg} / \mathrm{kg})$ in soil, volume $\left(\mathrm{m}^{3}\right)$ of soil used and the mass ( $\mathrm{g}$ ) of organisms utilized.

\section{RESULTS AND DISCUSSION}

Microbiology Analysis: Microbiological analysis carried out towards the isolation and identification of organisms yielded the selected organisms from the biochemical distinguishing of characters among the colonies $\left(2.8 \times 10^{4} \mathrm{cfu} / \mathrm{ml}\right.$ and $\left.1 \times 10^{3} \mathrm{sfu} / \mathrm{ml}\right)$ that developed after incubation. The bacteria were distinguished with the respective biochemical 
indications of gram stain, catalase, oxidase, indole, citrate, glucose, lactose, $\mathrm{H}_{2} \mathrm{~S}$ and motility as Arthrobacter nicotiniae (positive, negative, negative, positive, positive, positive, negative and negative); Bacillus subtilis (positive, positive, negative, negative, positive, positive, negative and positive); Klebsiella pneumoniae (positive, negative, negative, positive, positive, negative, negative and negative); Proteus mirabilis (positive, negative, negative, negative, positive, positive, positive and positive); and the fungi characterized as documented in Table 1.

Optimum Factors: Vital factors have been discovered to have significant influence on biosorption process and rate (Atikpo et al., 2015; Murthy et al., 2012). This has necessitated that these factors are studied with an aim to select their optimum values necessary for this biosorption study (Atikpo, 2016). The impacts of 2, 4, $6,8,10,12$ and $14 \mathrm{ml}$ of nutrient; $1,2,3,4,5,6$, and $7 \mathrm{~g}$ organisms; $20,25,30,35,40$ and $45^{\circ} \mathrm{C}$ temperature for bacteria and $10,15,20,25,30$ and $35^{\circ} \mathrm{C}$ for fungi; 4, 5, 6, 7, 8, 9 and 10 of $\mathrm{pH}$; and $0,1,2,3,4,5$ and 6 per week (pw) of stirring frequency on $\mathrm{Pb}$ biosorption by the organisms were studied for 14 days to obtain optimum values through screening. A criterion of least concentration remaining was engaged in identifying these optimum factors as shown in Table 2.The respective optimum values of nutrients' volumes, organisms' weights, temperature, $\mathrm{pH}$ and stirring frequency were recognized and selected at the respective least concentration remaining of 101.11, 103. $93.51,94.12$ and $95.12 \mathrm{mg} / \mathrm{kg}$ for Bacillus subtilis; 123.42, 124.32, 106.12, 117.61 and 115.32 $\mathrm{mg} / \mathrm{kg}$ for Proteus mirabilis; 99.28, 102.64, 96.11, 97.35 and $92.09 \mathrm{mg} / \mathrm{kg}$ for Klebsiella pneumoniae; $103.46,119.45,110.14,117.43$ and $120.31 \mathrm{mg} / \mathrm{kg}$ for Onychocola canadensis; 100.29, 117.37, 116.27, 120.32 and $119.11 \mathrm{mg} / \mathrm{kg}$ for Trichophyton interdigitae; and 88.51, 95.58, 92.42, 96.16 and 94.66 $\mathrm{mg} / \mathrm{kg}$ for Arthrobacter nicotiniae.

Removal Capabilities: Figure 1 is a graphical display of the influences exerted by the organisms for the removal of the metal. The organisms' order of removal influence is Arthrobacter nicotiniae, Bacillus substilis, Klebsiella pneumoniae, Proteus mirabilis, Trichophyton interdigtae and Onychocola Canadensis. And the removal of this metal by the microorganisms showed similar trend, and increased generally with time. These organisms were able to reduce this metal from the initial concentration of $181.41 \mathrm{mg} / \mathrm{kg}$ to a concentration below the maximum allowable concentration of $100 \mathrm{mg} / \mathrm{kg}$ specified in (Word Health Organization - WHO, 2001; Pandias, 1992); and this occurred at different times for the organisms depending on their removal strengths. This occurred for Proteus mirabilis at time 21 days, with a residual concentration of $87.54 \mathrm{mg} / \mathrm{kg}$ and concentration removed of $93.81 \mathrm{mg} / \mathrm{kg}$ and an efficiency of $51.74 \%$.

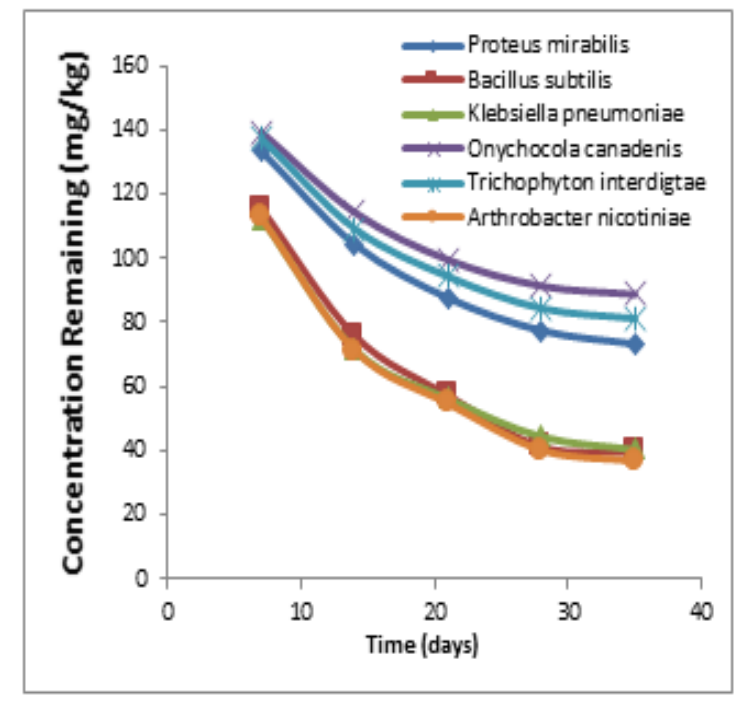

Fig 1. Comparative Removal of Lead by the Microorganisms

This residual concentration fell with time until it got to a concentration value of $73.17 \mathrm{mg} / \mathrm{kg}$ at time 35 days with an amount removed of $108.24 \mathrm{mg} / \mathrm{kg}$ and 59.67 $\%$ efficiency. For Bacillus subtilis, the soil $\mathrm{Pb}$ ion fell below the maximum allowable at time 14 days with a residual concentration of $75.74 \mathrm{mg} / \mathrm{kg}$ at an amount removed of $105.74 \mathrm{mg} / \mathrm{kg}$, and efficiency of $58.25 \%$. This residual concentration fell until it reached 39.46 $\mathrm{mg} / \mathrm{kg}$ on the $35^{\text {th }}$ day with a removed concentration of $141.95 \mathrm{mg} / \mathrm{kg}$ and $78.25 \%$ efficiency. Klebsiella pneumonia removed the metal below the maximum allowable concentration at time 14 days. The concentration remaining at this time was $71.41 \mathrm{mg} / \mathrm{kg}$ with an amount removed of $102.26 \mathrm{mg} / \mathrm{kg}$ and 60.64 $\%$ efficiency. This concentration remaining further dropped with time until it got to a value $43.20 \mathrm{mg} / \mathrm{kg}$ at time 35 days, which is a concentration after a removal of $133.65 \mathrm{mg} / \mathrm{kg}$ with $76.19 \%$ removal efficiency. Unlike the organisms in the two preceding paragraphs, Onychocola canadensis dropped the lead concentration below the maximum allowable limit at time 21 days with a concentration remaining of 99.42 $\mathrm{mg} / \mathrm{kg}$ at an amount removed of $81.99 \mathrm{mg} / \mathrm{kg}$ and $44.65 \%$ efficiency. This concentration remaining further fell with time until it hit a concentration value of $88.65 \mathrm{mg} / \mathrm{kg}$ at time 35 days with an amount removed of $92.76 \mathrm{mg} / \mathrm{kg}$ and a removal efficiency of $51.13 \%$. Similarly, Trichophyton interdigitae reduced the concentration below the maximum allowable concentration at time 21 days with a value of 94.21 $\mathrm{mg} / \mathrm{kg}$ for the residual concentration at an amount removed of $87.20 \mathrm{mg} / \mathrm{kg}$ and $48.07 \%$ removal 
efficiency. This residual concentration dropped with time to a value of $81.14 \mathrm{mg} / \mathrm{kg}$ at time 35 days, with an amount removed of $100.27 \mathrm{mg} / \mathrm{kg}$ at a removal efficiency of $55.27 \%$. The concentration remaining under the influence of Arthrobacter nicotiniae came bellow the maximum allowable at time 14 days with a residual concentration value of $71.12 \mathrm{mg} / \mathrm{kg}$ at an amount removed of $110.29 \mathrm{mg} / \mathrm{kg}$ and efficiency of $60.80 \%$. There was a fall in the residual concentration with time until it hit a value of $36.68 \mathrm{mg} / \mathrm{kg}$ at time 35 days. This happened at an amount removed of 144.73 $\mathrm{mg} / \mathrm{kg}$ and $79.78 \%$ removal efficiency. These are summarily shown in Table 3.

Table 1. Identification of Fungal Isolates

\begin{tabular}{llll}
\hline Isolates & Cultural Characteristics & Morphological Characteristics & $\begin{array}{l}\text { Identified } \\
\text { Organism }\end{array}$ \\
\hline $\begin{array}{l}\text { Organism } \\
1\end{array}$ & $\begin{array}{l}\text { Large fluffy white cottony } \\
\text { colonies which later turned black } \\
\text { as culture ages. }\end{array}$ & $\begin{array}{l}\text { Non-septate hyphae with upright } \\
\text { sporangiophore connected by stolon and } \\
\text { rhizoids bearing dark peer-shaped sporangium } \\
\text { on hemispherical columella. }\end{array}$ & $\begin{array}{l}\text { Trichophyton } \\
\text { interdigitae }\end{array}$ \\
Organism & $\begin{array}{l}\text { White mycelia which covered the } \\
\text { surface of plate rapidly and } \\
\text { turned with age. }\end{array}$ & $\begin{array}{l}\text { Hyphae were non-septate, sporangiophore were } \\
\text { long branched and bore terminal sporangia. }\end{array}$ & $\begin{array}{l}\text { Onychocola } \\
\text { canadensis }\end{array}$ \\
\hline
\end{tabular}

Table 2. Selected Optimal Factors for Biosorption Studies

\begin{tabular}{|c|c|c|c|c|c|c|}
\hline \multirow[t]{2}{*}{ Factors } & \multicolumn{6}{|c|}{ Micro Organisms Utilized } \\
\hline & $\begin{array}{l}\text { Proteus } \\
\text { Mirabilis }\end{array}$ & $\begin{array}{l}\text { Bacillus } \\
\text { Subtilis } \\
\end{array}$ & $\begin{array}{l}\text { Klebsiella } \\
\text { Pneumoniae }\end{array}$ & $\begin{array}{l}\text { Onychocola } \\
\text { canadensis }\end{array}$ & $\begin{array}{l}\text { Trichophyton } \\
\text { Interdigitae }\end{array}$ & $\begin{array}{l}\text { Arthrobacter } \\
\text { nicotiniae }\end{array}$ \\
\hline $\begin{array}{ll}\text { Weight } & \text { of } \\
\text { Organism }(g) & \end{array}$ & 1 & 5 & 5 & 1 & 1 & 1 \\
\hline $\begin{array}{l}\text { Volume of Nutrient } \\
(\mathrm{ml})\end{array}$ & 8 & 8 & 12 & 10 & 8 & 6 \\
\hline Temperature $\left({ }^{\circ} \mathrm{C}\right)$ & 30 & 30 & 30 & 25 & 25 & 30 \\
\hline $\mathrm{pH}$ & 7 & 8 & 7 & 7 & 6 & 7 \\
\hline $\begin{array}{l}\text { Stirring Frequency } \\
(\mathrm{pw})\end{array}$ & 6 & 6 & 6 & 6 & 6 & 6 \\
\hline & Tab & : Informa & on on Lead Pol & tion Contro & th the Organisms & \\
\hline Organism & $\begin{array}{l}\text { Time } \\
\text { (Day: } \\
\text { Redu } \\
\text { Ion t } \\
\text { Stanc }\end{array}$ & $\begin{array}{l}\text { in } \\
\text { to } \\
\text { Lead } \\
\text { Below } \\
\text { ards }\end{array}$ & $\begin{array}{l}\text { Residual } \\
\text { Lead Ion at } \\
\text { initial time of } \\
\text { Pollution } \\
\text { Control } \\
(\mathrm{mg} / \mathrm{kg})\end{array}$ & $\begin{array}{l}\text { Efficiency } \\
(\%)\end{array}$ & $\begin{array}{l}\text { Residual } \\
\text { Concentration } \\
\text { at 35 Days in } \\
(\mathrm{mg} / \mathrm{kg})\end{array}$ & $\begin{array}{l}\text { Efficiency } \\
(\%) \text { at } 35 \\
\text { Days }\end{array}$ \\
\hline Proteus mirabilis & 21 & & 87.54 & 51.74 & 73.17 & 59.67 \\
\hline Bacillus substilis & 14 & & 75.74 & 58.25 & 39.46 & 78.25 \\
\hline Klebsiella pneumonia & 14 & & 71.41 & 60.64 & 43.20 & 76.19 \\
\hline Onychocola Canadensis & 21 & & 99.42 & 44.65 & 88.65 & 51.13 \\
\hline Trichophyton interdigtae & 21 & & 94.21 & 48.07 & 81.14 & 55.27 \\
\hline Arthrobacter nicotiniae & 14 & & 71.12 & 60.80 & 36.68 & 79.78 \\
\hline
\end{tabular}

Conclusion: The study showed that these organisms can be utilized to remove $\mathrm{Pb}$ ion from Amaonye Ishiagu forest soils. Arthrobacter nicotiniae showed the greatest removal capacity with time, followed by Bacillus substilis, and then Klebsiella pneumoniae; before Proteus mirabilis, Trichophyton interdigtae and Onychocola canadensis in that order. The removal of this metal by the microorganisms followed similar trends; and closeness in removal abilities is seen in removals by Anthrobacter nicotiniae, Bacillus substilis and Klebsiella pneumoniae.

\section{REFERENCES}

Athar, M; Vohora, SB (2006). Heavy Metals and

Environmental. New Age International (P)
Limited Publishers, 4835/24, Ansari Road, Daryaganji, New Delhi-110002.

Atikpo, E (2016). Spatial Distribution and Attenuation of Heavy Metals Pollution in Amaonye-Ishiagu Forest Soils. A PhD Thesis Submitted to the Department of Civil Engineering, University of Benin, Benin City, Nigeria.

Atikpo, E; Anyata, BU; Mokwenye, II (2015). Variation of Factors for Metals Removal: a Guide to Factors Selection for Bioremediation of Heavy Metals Polluted Soils in Amaonye-Ishiagu of Ebonyi State in Nigeria. J. Civ. Environ. Sys. Engi.13:172-181. 
Badawy, RK; El-Gawad, AMA; Osman, HE (2013). Health Risks Assessment of Heavy Metals and Microbial Contamination in Water, Soil and Agricultural Foodstuff from Waste Water Irrigation at Sahl El-Hessania area, Egypt. J. App. Sci. Resea. 9(4):3091-3107.

Badmus, MAO; Audu, TOK; Anyata, BU (2007). Removal of Lead Ion from Industrial Wastewaters by Activated Carbon Prepared from Periwinkle Shells (Typanotonusfuscatus). Turk. J. Envi. Engin. Sci. 31: 251-263.

Barnet, HL; Hunter, BB (1972). Illustrated General of Imperfect Fungi. Burgess Publishing Company, Minneapolis.

Baron, EJ; Peterson, LR; Finegold, SM (1994). Bailey and Scotts Diagnostic Microbiology. $9^{\text {th }}$ Edition. Mosby, Baltimore.

Begum, A; Ramaiah, M; Harikrishna, O; Irfanulla, K; Veena, K (2009). Analysis of Heavy Metals Concentrations in Soil and Litchen from Various Localities of Hosur Road, Bangalore, India, CODEN ECJHAO, E-A. J. Chem. 6(1): 13-22.

Chessebrough, M (2000). District Laboratory Practice in Tropical Countries. Part 2, Cambridge low Price Edition, Cambridge University Press, London.

Cowan, ST (1993). Cowan and Steels Manual for the Identification of Medical Bacteria. Cambridge University Press, London.

Cowan, ST; Steel, R (1990). Manual for the Identification of Medical Bacteria. Cambridge University Press, London.

Ezeh, HN; Chukwu, E (2011). Small Scale Mining and Heavy Metals Pollution of Agricultural Soils: the Case of Ishiagu Mining District, South Eastern Nigeria. J. Geo. Min. Rese. 3(4): 87-104.

Hanigan, WJ; McCane, EM (2002). Laboratory Methods in Foods and Dairy Microbiology. Fourth Edition, Academic Press, London, New York.
Holt, JC (1994). The Shorter Bergeys Manual of Determinative Bacteriology. Eight Edition, Williams and Willkins Company, Baltimore.

Lima, EC; Royer, B; Vaghetti, JCP; Brasil, JL; Simon, NM; Dos S Jr., AA; Pavan, FA; Dias, SLP; Benvenutti, EV; Da Silva, EA (2007). Adsorption of $\mathrm{Cu}$ (II) on Araucaria Angustifolia wastes: Determination of the Optimal Conditions by Statistic Design of Experiments. J. Hazar. Mate. 140: 211-220.

Murthy, S; Bali, G; Sarangi, SK (2012). Biosorption of Lead by Bacillus cereus Isolated from Industrial Effluents. Brit. Biotech. J. 2(2): 73-84.

Nwaugo, VO; Onyeagba, RA; Akubugwo, EI; Ugbogu, S (2008). Soil Bacterial Flora and Enzymatic Activities in Zinc and Lead Contaminated Soil. BIOK. 20(2): 77-84.

Pendias, AK; Pendias, H (1992). Elements of Group VIII. In: Trace Elements in Soils and Plants. Boca Raton: CRC Press.

Shu, JM; Wang, JJ; Liu, XC (1998). Ecological Restoration of Mining Wasted Lands, China Population. Resou. Envir. 8(3): 72-75.

Sobolev, D; Begonia, MFT (2008). Effects of Heavy Metal Contamination upon Soil Microbes: LeadInduced Changes in General and Denitrifying Microbial Communities as Evidenced by Molecular Markers. Int. J. Environ. Res. Pub. Hea. 5(5): 451.

Vargas-Garcia, MDC; Lopez, MJ; Suarez-Estrella, F; Moreno, J (2012). Compost as a Source of Microbial Isolates for the Bioremediation of Heavy Metals: in Vitro Selection. Sci. Tot. Envir. 431: 62-67.

World Health Organization (2001). Health Guidelines for the Use of Waste Water in Agriculture and Aquaculture. Report of a Scientific Group Meeting, Technical Report Series, No. 778, World Health Organisation, Geneva. 